\title{
Analysis on Character's Behavioral Alienation in Sula
}

\author{
Rui Yan \\ Zhejiang Yuexiu University, Shaoxing, China \\ Email: 20202018@zyufl.edu.cn
}

How to cite this paper: Yan, R. (2022) Analysis on Character's Behavioral Alienation in Sula. Open Access Library Journal, 9: e8329.

https://doi.org/10.4236/oalib.1108329

Received: December 27, 2021

Accepted: January 27, 2022

Published: January 30, 2022

Copyright () 2022 by author(s) and Open Access Library Inc.

This work is licensed under the Creative Commons Attribution International License (CC BY 4.0).

http://creativecommons.org/licenses/by/4.0/

\section{(c) (i) Open Access}

\begin{abstract}
As a woman writer with multi-layered vision, Toni Morrison exhibits herself distinctly in American literary canon, becoming the most prominent black female writer. In her novel Sula, she abandons traditional narrative method, inaugurating a new viewpoint to describe living conditions that are often overlooked among black community, aiming at revealing the alienation of black souls caused by racial discrimination for a long period. Combined with the method of close reading, the paper explores three forms of behavioral alienation in the novel. The first is concerned with the alienation of black males who are originally ordinary citizens at the bottom of a hierarchy having transformed into executioners of the tragedy with the erosion of false values related to some comprehensive factors concerning family and social environment. The second alienation is manifested as the distortion of sexual relationships through the transgression and encroachment of marriage ethics. The last is addressed as the loss of national responsibility as well as identity recognition among whole black communities.
\end{abstract}

\section{Subject Areas}

Literature

\section{Keywords}

Toni Morrison, Sula, Behavioral Alienation, Racial Discrimination

\section{Introduction}

As a woman writer with multi-layered vision, Toni Morrison exhibits herself distinctly in American literary canon and becomes an archetype of renown female writers at the height of creativity in contemporary American literature, with her works outlining and responding to a particular cultural group. As a goodness 
in American literary history, she privileges her cultural identity and expresses her opinions publicly: "I am valuable as a writer because I am a woman." [1]. Realizing black had long been silenced, overlooked and distorted in novels, she sympathetically created literary works composed of richly detailed black personalities and female dispositions to illustrate her writing goal that a writer should rediscover female experience and regain identity recognition. Consequently, she is dedicated to depicting characters who supersedes questions of gender and race, comprehending the exclusion of African and African American cultural experiences from the hegemonically constructed history of the United States [2].

Her famous novel, Sula, is written in a black vernacular manner filled with colorful turns of phrase and figures of speech, which are peculiar to the black community with the purpose that her work is in compatible with life. The character of the novel is a rebellious figure named Sula who is the victim of culture hegemony for she is not only neglected by her own parents but also be despised by the external circumstance. Contrary to her compatriots robbed of cultural identity, she represents black people transcending physical appearance manifested as black skin. Moreover, she interprets black individuality and resists to social conventions in a profound manner. There seems to gather around her name a halo of "disorderliness" since she refuses to comply to the disciplines imposed by community. In the end, Sula is scandalized by her companion. Ironically, the rest of community members are chastised to face the mundane reality and sunk into an artificial cage made of continuous death and natural disasters. Combined with the method of close reading, the paper demonstrates three forms of behavioral alienation. First, it probes into the alienation of black males who are originally ordinary citizens at the bottom of a hierarchy having transformed into victimizers considering marriage as a survival tool to reassure self-esteem. Besides, the paper concentrates on distortion of sexual relationships through depiction of transgression of marriage ethics. Thirdly, it explores the loss of national responsibility as well as identity recognition among whole black communities. The paper aims to raise awareness of regaining discursive power for those compatriots who live on the margin of society.

\section{Literature Review}

With the growing public awareness of the politics, literary criticism emphasizes the autonomy of the text from its cultural background where narrative voice and discourse power have been weakened. Since Toni Morrison has been awarded Nobel Prize in literature in 1993, the novelist and her works all enjoy a rapid growing body of literary critics, thus there have been many researches done of this novel in succession due to the collaboration of readers and literary critics. Henceforth, this part is dedicated to making a comprehensive and elaborative review of researches concerning Toni Morrison and her fabulous novel Sula. 


\subsection{Studies of Morrison's Work}

\subsubsection{The First Stage: 1970s}

Based on the existing different interpretations, the study of Morrison's works is divided into three stages in American academic field. The first stage is in the 1970s. At that time, the critics mainly concentrated on European and American modernism standards of literature, analyzing novel's themes in a profound manner. Due to the manipulation of white people, there only existed occasional articles in journals such as Black Literature Forum. Therein, the first official academic paper concerning Morrison's novel was Joan Bischoff's "The Novel of Toni Morrison: Studies in Thwarted Sensitivity" which was published in Studies in Black literature in 1975, putting emphasis on thematic analysis through detailed analysis of characters in The Bluest Eye and Sula. As for theoretical analysis, the prominent leader of this period was Barbara Smith, whose epoch-making article "Toward a Black Feminist Criticism" concerning the relationship between black female movements and literary creation as she intended to break the massive silence which has surrounded the work of these women writers and to make some connections between the politics of Black women's lives, their subject matter and their situation as artists [3]. In a sense, she had been called the first scholar to study Morrison's novel from the perspective of feminism. On the one hand, she acutely illustrated the close relationship between the two objects mentioned above. On the other hand, she remorselessly attributed the diminishment of black women's creation to rampant white critics, holding on the belief that there permeates an atmosphere of feminism all through the rebellious character, thus it is advisable to excavate the potential womanism through the theory of "Black Feminist Criticism".

\subsubsection{The Second Stage: $1980 \mathrm{~s}-1990 \mathrm{~s}$}

The next stage is from late 1980s to 1990s with the publication of Tar Baby, indicating that researches on Morrison have proceeding to a new stage. Essays and researches sprang up successively when critics were largely restricted in feminist approaches, deconstructionist, racial politics as well as cultural theories. In 1985, the first academic monograph The World of Toni Morrison: Explorations in Literary Criticism related to Morrison came by Bessie W. Jones, opening a new era of analyzing black African's novel in terms of quality and quantity.

The illustration of each classification would be listed as follows. The first category lies on the relationships between Toni Morrison and feminism. Therein, Barbara Christian published the book named Black Women Novelists. The Development of a Tradition, symbolizing that critic's attention has been shifted to feminism. Nellie Mackay also supported that Morrison is a determined feminist since she distinguishes between black and white feminist literary traditions, contemporary black women writers, however, look to the examples of their grandmothers, mothers, aunts, and sisters to continue powerful heritage that is not white and not male [4]. The second category turns out to be the tradition of black literature. A book concerning representative literary works of Toni Morri- 
son and Frederick Douglass, The Spiritual empowerment in Afro-American Literature, written by James $\mathrm{H}$. Evans in 1987, typically fortified the theme that black culture tradition was of vital importance in pushing forward the healthy development of native black people, clarifying the relationships between Toni Morrison and black literature tradition. The completion of it encourages critics to hold on the view that Morrison's novels are extraordinary products black community.

\subsubsection{The Third Stage: $1990 \mathrm{~s}-$}

The third stage is the booming time. In the widening analytical perspectives, experts have enriched their understandings, which veers from focusing on traditionally feminist angle to associating modern western literature theory with historical culture criticism. Typical critics are listed as follows. Nancy J. Peterson, who had deeply integrated black women criticism, post modernism with culture interference, wrote an academic article "Introduction: Canonizing Toni Morrison" in the journal Modern Fiction Studies which drew the dividing line for an utterly different and new perspective [5]. Typically, Susan S. Lanser mainly dealt with the transformation of women narrative voice. The tendency of individual narration exactly illustrates the third narrative pattern, communal voice [6]. Apart from diverse approaches of criticism listed above, there also existed an up-todate approach through the implementation of trauma theory which is suitable to analyze literary works produced by Jews and ethnic minority women. The prominent advocator turns out to be J. Books Bouson with his magnum opus Quiet as It s Kept. Shame, Trama and Race in the Novels of Toni Morrison. Her treatise is of significance to offer an in-depth elucidation of Toni Morrison's representation of painful and shameful race matters. Quiet as it's kept, much of our business, our existence here, has been grotesque [7].

\subsection{Comprehensive Researches on Sula}

The novel Sula, with its emphasis on depicting leading character figuratively, receives considerable reputation in academic circles, as Karen F. Stein simply declares, the book's vision, like that of the heroic tale, is of human life played out against a background of natural and supernatural forces [8].

The publication of Sula coincided with the zenith of the second wave of feminism, lifting tempestuous waves in the academic circle and triggering unprecedented discussions and analyses in 1973, just as J. Brooks Bouson described that Sula occupied a significant position in Contemporary American literature since it gave rise to a kind of critical stampede [7]. At that time, consciousness-raising groups calls for gender solidarity dominated the discussions of women in America [9]. What's more, advocators of the second wave of feminism indicted violence, looking for methods to pull women out of living plight with an attempt to raise women's independence and perseverance. However, there also existed opponents who did not appreciate Morrison's craftsmanship. Typical example is Sara Blackburn, expressing her revulsion towards Sula critically. If she is to main- 
tain the large and serious audience she deserves, she is going to have to address a riskier contemporary reality than this beautiful but nevertheless distanced novel [10].

Taken together, criticism with respect to Sula overseas could be divided into several categories. The first stage was 1970s when schools of critics concentrated on European and American modernism standards of literature, analyzing novel's themes in a profound manner. Barbara Smith, a prominent advocator of feminism had given rise to an essay named "Toward a Black Feminist Criticism", with its emphasis on theoretical analysis. Compared to other womanists, Smith called reader's attention insightfully to the illustration of Sula's personality. Instead of considering characters in this novel as a poignant example of sisterhood as many critics may contend, Smith determinedly deemed that this novel touched upon the subject of lesbian. During the 1970s, another representative of feminism, Simone de Beauvoir made a strenuous effort to analyze Sula employing feminist consciousness. She not only added a sense of heroism into the title character, Sula, exploring feminist icon Sula represents, but also illuminated that Sula serves as an archetype for womanist who refuses to abide by social conventions and craves for individuality and independence.

Consequently, during 1980s, schools of criticism embarked on the process of dissecting novel through the combination of African cultural elements. There is an unprecedented surge of cultural criticism in Academic circle, such as Barbara Christian who discussed Sula in book Black Women Novelists. The Development of a Tradition: 1892-1976. Structure of the novel and representative female figures are highlighted, lying stress on the value of self-independency and bravery Sula embodies. Furthermore, she gave high praise to Morrison's refined craftsmanship declaring that Morrison's novels do not yield to easy generalizations and nicely packaged clichés, and she resists the trends of the times without discarding the truths upon which they are based [11]. Additionally, some scholars illuminated the relationship between Morrison's technology of narration and her racial identity following chronological order. One of the prominent example is Patricia Mckee, strives to distinguish between systematic spacing arrangements, of the kind necessary to a symbolic order [12]. Highlighting the point that Morrison designedly identifies both failed possessions of places and failed actions, Mckee declared that Morrison placed missed absence and presence in the novel.

Another critical approach to illuminate the novel is to dissect the friendship between two characters Nel and Sula. Sula encompasses different characteristics of females which Morrison explains that this novel is concerned with Sula's childhood friendship with her one great companion [13]. Morrison's approach to friendship is captured by Cassandra Fetters' latest article named "The Continual Search for sisterhood" which contends that numerous problematic attachments undermine feminism and sentimental fantasies about difference-defeating sisterhood obfuscate the recognition of other, separate subjects [9]. 
Although there existed several papers discussing about character' behavioral alienation, it does not have complete analysis. Given this, the paper breaks through traditional research method to look deeper into black people's faulty life and manifestations of this from a wider perspective systematically and profoundly through probing into the inner causes of this alienation phenomenon according to tragic results they bring, in an attempt to raise awareness of regaining national discourse for those compatriots who live on the edge of society.

\section{The Alienation of Black Males}

Character's behavior alienation, a terminology in classical German philosophy, is built up gradually integrating itself with Marxist theory. Its original meaning refers that the property of the individual shifts into somebody else's property gradually, whereas in this paper it indicates a kind of psychological experience where people find themselves are not familiar with as before. In the historical reference, jobs and rights which give preference to white people are injected to black people's ideas in Sula. Therefore, black people are doomed to descend to others consciously or unconsciously and alienation seems to be unavoidable.

\subsection{The Alienation of Scapegoats}

The first alienation is concerned with the alienation of scapegoats who are originally ordinary citizens at the bottom of a hierarchy having transformed into executioners of the tragedy. Persecuted in that extremely unjust society, black males are forced to be scapegoats of white people, enduring racial discrimination constantly. In the sense of Judaist sacred ceremony, the scapegoat has been connected with a process where lambs have to be sacrificed because of sinners shifting the evil on them. This connotation can be expanded to people who undertake the obligations resulting from other people's faults. Consequently, the term "scapegoat" in this novel refers to black males who endure sufferings and humiliations from white people. Those innocent lambs which deserve compassion have been degraded into potential abusers, but this abnormal alteration does not seem to be a rare phenomenon.

Acting as representatives of those scapegoats, some black people, such as Boyboy, maltreats his wife Eva to build self-esteem; the others like Jude and Ajax, they abandon their beloved and shrink responsibilities of acting as role of "husband" and "father". They are alienated to victimizers considering marriage as a survival tool to reassure self-esteem, degenerating to executioners of family tragedy, which reminds that our beautiful black boys before they leave us, to consider any difficulties between black men and women in a cultural as women as racial and sexual context [14].

In the novel, Boyboy abandons Eva; Jude abandons Nel and Ajax discards Sula. Jude is a scapegoat since racism robs him of due working rights so that he cannot be engaged in decent work to satisfy his vanity. Instead, what awaits him is sleazy and less-paid work. Jude is indulged in the dream that he wields sledge 
hammer to carve out a new path wearing heavy work shoes and rough work clothes with his comrades. Thus along with a few other young black men, Jude had gone down to the shack where they were hiring [15] with full hope only to be granted with unjust treatment. It was after he stood in lines for six days running and saw the gang boss picks out thin-armed white boys and the bull-necked Greeks and Italians [15]. Admittedly, scare, shame and disgrace have been integrated and crowded into Jude's mind at that time, still it was a shame to see those white men laughing with the grandfathers but shying away from the young black men who could tear that road up [15].

Once one has realized himself being humiliated, he does not make it clear that the source of it springs from white man's blatant disdain. When shame comes out, out of protection, people may shift their discontents to other people. Jude finds nowhere to release resentment, therefore he can only transform distress to people inferior to him in that patriarchal society. It was rage and a determination to take on man's role anyhow that made him press Nel about settling down [15]. The reason of Jude proposing to Nel is not because of true love, but because he wants to fulfill his appetites, to secure a sense of manhood in the patriarchal society. He chose the girl who had always been kind, who had never seemed hellbent to marry, who made the whole adventure seem like his idea, his conquest [15]. In Jude's view, home is a sanitarium to release painful working experience, to diagnose pain and to spit at Nel who must be submissive and meet his requirements under any condition. Considering black woman as inferior existence, Jude, a scapegoat in the white dominated society, cannot resist the temptation of Sula. As a result, he relentlessly betrays Nel, discards her at his will thus becoming a victimizer of family tragedy.

\subsection{The Alienation of Shadrack}

Morrison creates Shadrack, another eccentric man in the novel, to reinforce inevitability of the alienation. She defies it most dramatically through her revision of the figure of the veteran suffering from post-traumatic stress [16]. She pays an intermittent attention to describe his living plight, his abnormal behavior and his relationship with Sula. On the one hand, he seems to be isolated from the community since he spreads his message of establishing National Suicide Day in Medallion. It is obviously seen that Shadrack's spiritual world is alienated since he consistently walks through the Bottom down the Carpenter's Road with a cowbell and a hangman's rope calling the people together [15]. Moreover, Shadrack never ceases to bring his cowbell and rope even on the condition that a large proportion of community residents are died of disaster. Having forgotten his song and his rope, he just stood there high up on the bank ringing, ringing his bell [15]. Such eccentric behavior not only indicates that Shadrack is alienated in the spiritual level, but also insinuates that world war which Shadrack undergoes several years ago has a far-reaching and inveterate effect on him, casting an enormous shade over his heart. Living on the fringe of the community, Shadrack 
presents himself to be insulated from whole community and refuses to pay respect to town residents.

Shadrack's alienation is triggered by ruthless war and racial discrimination. His whole life is abundant in unceasing war, violence, blood, tease and abandonment. Afflicted and tortured by ruthless war, Shadrack tries utmost to get rid of the control of war. In chapter 1919, Shadrack was "blasted and permanently astonished by the event of 1917" although he has never undergone it previously. Morrison makes it clear the striking transformation that Shadrack has after he comes back from the battlefield. Previously Shadrack is a naïve, innocent and romantic young people who has no chance to get acquainted with evil and violence. But stubbornly, taking no direction form the brain, the body of the headless soldier ran on, with energy and grace, ignoring altogether the drip and slide of brain tissue down its back [15]. The above description provides a broad panorama of desolate and alienated heart in which war has trampled. Tortured by brutal war and under the impingement of mainstream white culture, he cannot help remembering dreadful events taken place in the battlefield and anything which may have connection with war would trigger miserable memories. When Shadrack awakes from the nightmare, he joyfully finds that before him on a tray was a large tin plate divided into three triangles. In one triangle was rice, in another meat, and in the third stewed tomatoes [15]. Stewed tomatoes, embodiment of blood, remind Shadrack of all the anguish he has suffered. Therefore, his mind is abundant with fantasy and madness. Mayberry once discusses Shadrack's abnormal behavior in depth, holding on the view that since Shadrack is confined in the hospital because of his disruptive panic or the hospital's lack of space, Shadrack is immediately confronted with what to him is the bewildering chaos of grounds and floating paperdoll people [14], falling into an illusion that those paperdoll people would vanish with the wind, which could also be considered as a prominent manifestation of Shadrack's alienation.

Alienated as Shadrack is, his outwardly ramshackled but inwardly pristine shack is a metaphor for his state of being [14], he is almost robbed of sanity and cannot distinguish reality from dreadful nightmare. The uncontrollable fingers insinuate unrestricted destructiveness hidden in his heart triggered by war. When he begins to enjoy dinner, he directed one hand toward the cup and just as he was about to spread his fingers, they began to grow in higgledy-piggledy fashion [15], disrupting original soothing equilibrium of the appetizing food. Most importantly, he consistently avoids his eyes watching his fingers and fumbled with the laces of the heavy high-topped shoes [15]. Those descriptions of Shadrack's aberrant behaviors all present to be the strongest weapons that war has imprinted an indelible print, accounting for the reason that he struggles to free himself from the constraint of unpredictable death abiding by the rule of discovering light in darkness and preserving sanity in mania after war.

\subsection{Further Reasons of the Alienation of Black Males}

Freud once states that only when industry and political system go hand in hand 
with mental outlook can social alienation be eliminated. From this point of view, an inference can be made that black people's mental activities are in inconformity with rapid economic progress that results in the alienation of black males. The alienation of black males results from black people's confusion, distortion and loss under racial discrimination and gender oppression. It manifests the loss of healthy and balanced family relationship through highlighting the profound impact of some scapegoats who are originally victims in the society having transformed into executioners of family tragedy. Since the beginning of the transmission of black people to America, black slaves lived in such subhuman conditions and are stamped into humble symbols. For the sake of own profits, slaveholders indoctrinate notions into innumerable slaves that they are servile by nature and are equivalent to animals. Discrimination for a long period have formed the idea that Black people is subordinated to white people unconsciously under the pressure of the racial oppression. As a matter of fact, political system, superstructure, economic foundation and ideology are all manipulated through white people's intense control. Consequently, jobs and opportunities are all determined invisibly. Black males rely on their advantages in the patriarchal society in the way of despising black females who live on the fringe of society.

\section{The Alienation of Sexual Relationships}

The second category of alienation refers to the alienation of females, manifested as disordered sexual relationships. Morrison is specialized in portraying black childhood and girlhood as they resonate with readers for touching hearts invisibly. The novel directs a critical gaze in the brutal process of enslaving black people, so that the alienation of female who are suffered from double oppression in the patriarchal society seems to be an inevitable process. Throughout the novel Sula, Eva, Hannah as well as Sula are distorted since they do not have steady and permanent relationships with males. Instead, their interactions with males are out of sexual impulses. Consequently, their marriage appears to be in imbalanced and disordered conditions manifested as unrestrained and immoral sexual intercourses.

Through Morrison's vivid narrations of Hanna and Sula's unrestrained sexual experiences, readers manage to be more bearable to unrestrained sexual behavior in Sula's family which largely results from the absence of paternal love. Paternal love becomes an indispensable part for the cultivation of children. The absence of paternal love can be traced back to the detrimental effect of deeprooted slavery, which remains many shortcomings for fatherhood construction in the future. Being far away from due obligation of fatherhood, the black people are accustomed to considering father only as an economic mainstay even if they have children.

Similar to Hanna, whose father abandons her in her early childhood, Sula is also trapped in the dilemma since her father dies in her early childhood, experiencing trauma of lacking paternal love. Hannah married a laughing man named 
Rekus who died when their daughter Sula was about three years old [15]. Thanks to the careful nurturing of her aunt, she could survive without worrying food and clothing. However, the psychological flaws caused by absence of parental love have gradually encroached on her mind, which are also manifested in her later life. It is owing to inadequate kindness from her father that generates her sense of fear, bewilderment and desperation, provokes the advent of her puberty and increases the risk of chaotic sexual behavior. Besides, her abnormal behavior could also be explained by subtle influence from her mother Hanna and grandmother Eva. Specifically, Eva's painful experience instills the mind of Sula with the idea that male is treacherous and unreliable. Moreover, Hanna cannot prohibit the torrent of inner emptiness and loneliness. As a result, her casual behavior ripples in Sula's heart in an unceasing pace, instructing Sula that "Sex was pleasant and frequent, but otherwise unremarkable". Witnessing her step so easily into the pantry and emerge looking precisely as she did when she entered, only happier [15], Sula begins to ponder over the question of sexual relationships and cannot resist the temptation with no consideration of her confidante's feelings.

With the above elements intertwined presented as paternal love and influence of mother's disgraceful conducts, Sula is not only more readily to hold negative attitudes toward males, but also displays herself as a prodigal female who even sleep with her confidante's husband. Possessing rebellious and eccentric disposition, she revolts against what is societal and restricted, construing sex as a method to relieve stress. It was the only place where she could find what she was looking for: misery and the ability to feel deep sorrow [15].

\section{The Alienation of Black Community}

Owing to racial discrimination and gender oppression, black people try to get rid of black identity and despise or banish his companion in the white-oriented society. They have always been in marginalized groups and besieged into artificial cages made of identity disintegration. As a result, this part is dedicated to expound the alienation of black community.

\subsection{Introduction to the Total Disintegration of Identity}

Self-identity is a non-negligible concept in western culture. Identity problems have been related to a series of theoretical problems such as subject, language, psychology, ideology, gender and ethnic. In comparison with other's evaluation, identity recognition must focus, as never before, on psychological and physical experience of ego. Racial and gender discrimination not only do harm to the black community, but also monopolize black people's thinking, making them being the indirect producers of Sula's tragedy. In the historical sense, black people were carefully inspected, stigmatized within their hearts, which never be resolved by Emancipation Proclamation. On the basis of Jung's theory, collective unconsciousness is made up with shared experience, which is also a potential 
mental mechanism. In the case of black people, ceaseless oppression which black people have been suffered from generates self-denying psychology and leads to the disintegration of identity.

Cultural identity crisis is equivalent to alienation of human nature, where people are upset and confused with their original culture, resulting in the consequence of hating their companions in an incredible manner. For a long period, African American have possessed dual cultural identity. On the one hand, they are eager to promote national culture; while at the same time, the social context does not offer adequate soil for their national seed to grow. Under various contradiction, black culture is doomed to be incompatible with oriented culture, thus black people are subordinated to alleged noble man who are forced to lose their self-identity and despise their compatriots. According to Nancy J. Peterson, the process of reading what we wrote or other imaginative literary works essentially means inspects our innermost feeling [5]. Peterson indicates that in arduously searching self-identity, black people has utilized narrative therapy to reconstruct themselves, to deconstruct dominant discourse, thus providing opportunities for themselves to utter their sufferings and to strengthen cultural identity.

\subsection{Black Community: Perplexed Losers of Black Subjectivity}

Cultural identity is a critical term in the postcolonial theory advocating that cultural hegemony not merely transforms values in colonial countries, but more importantly, gives rise to chances of loss of self-identity and subjectivity. Some black people with brown skins are consistently persecuted in the white-dominated society with an earnest wish to give up their egotism like hollow bamboos. It is evident that black community have expanded self-disintegration to a more serious degree. Self-alienation let alone, there exists a bitterly indifferent atmosphere within community companions that they do not care about or even make a bitter contempt of their fellows. In the novel, when Sula goes back to Medallion several years later accompanied by a plague of robins, none of people express their serene welcome except Nel. By the time she reached the Bottom, the news of her return had brought the black people out on their porches or to their windows. There are scattered hellos and nods but mostly stares [15]. Tragically, Eva, Sula's only kinship in the world, does not turn a finger to take care of her granddaughter.

Black community residents band together, fabricate several lies and hold on the view that it is Sula who upturns the calamity of town. For instance, when Sula decides to put Eva in Sunnydale, the people in the bottom shook their heads and said Sula was a roach [15]. Rumors spread every corner of the community and they remembered the plague of robins that announced her return, and the tale about her watching Hannah burn was stirred up again [15]. At the end of the novel, when Sula is in the fringe of death, neighbors do not turn a figure to save her from pain, instead, they make efforts in using bitter sarcasm to give Sula 
a second blow and drive the brave and distinguished lady to death. Sarcastically, Morrison depicts that the death of Sula Peace was the best news folks up in the Bottom had since the promise of work at the tunnel [15].

Those details mentioned above indicate that disdain in the community speeds up the pace of character's behavioral alienation. The whole black community are all immersed in morbid fantasies and banish their compatriots in order to seek psychological equilibrium. As a result, the alienation of human nature has become a widespread issue for those people who had been tamed and give up their voices.

\section{Conclusions}

As a Nobel Prize winner, Toni Morrison cannot be overlooked; her literary works not only add different voices for the treasure house of literature to some extent, but also claim dignity for black people who had once been robbed of human right physically and spiritually. In the paper, three categories of character's behavioral alienations are expounded respectively through the elaborate description of the slightest emotional difference between characters. The tragedy of character Sula and the alienation throughout the novel is a miniature of contemporary American marginal culture which is permanently being permeated, covered, subverted and subjugated by white culture.

Since human's barbarous treatment never gives rise to a barbarous nation, the alienation of black people is a severe issue to overall human civilizations. Therefore, the remedies can be undertaken accordingly to reestablish black people's cultural structure and to regain their national discourse. On the one hand, the lamentable victims all come from family members that are supposed to offer care and shelter, thus it's essential to rebuild and reconstruct sound family relationships. The weaker sense of family consciousness in Sula's family has hampered her healthy development, pushing her closer to a despair abyss, suggesting that when facing difficulties and obstacles, a harmonious and united family is the strongest weapon. On the other hand, black people should not only defend their cultures from being assimilated or diminished, but also construct nation identity recognition. Owing to the absence of black people's identity recognition, Morrison advocates equal economic and political rights for black people, providing reference for colored people who are still struggling for eligible rights in hot water.

\section{Conflicts of Interest}

The author declares no conflicts of interest.

\section{References}

[1] Mckay, N.Y. (1988) Critical Essays on Toni Morrison. G. K. Hall, Boston.

[2] Hunt, P. (1993) War and Peace: Transfigured Categories and the Politics of Sula. African American Review, 27, 443-457. https://doi.org/10.2307/3041934 
[3] Smith, B. (1979) Toward a Black Feminist Criticism. Women's Studies International Quarterly, 2, 183-194. https://doi.org/10.1016/S0148-0685(79)91780-9

[4] Mckay, N.Y. (1983) An Interview with Toni Morrison. Contemporary Literature, 24, 413-429. https://doi.org/10.2307/1208128

[5] Peterson, N.J. (1993) Introduction: Canonizing Toni Morrison. Modern Fiction Studies, 39, 461-479. https://doi.org/10.1353/mfs.0.0383

[6] Lanser, S.S. (1992) Fictions of Authority: Women and Narrative Voice. Cornell University Press, Ithaca. https://doi.org/10.7591/9781501723087

[7] Bouson, J.B. (1999) Quiet as It's Kept: Shame, Trauma, and Race in the Novels of Toni Morrison. State University of N.Y. Press, Albany.

[8] Stein, K.F. (1984) Toni Morrison's Sula: A Black Woman's Epic. Black American Literature Forum, 18, 146-150. https://doi.org/10.2307/2904289

[9] Fetters, C. (2016) The Continual Search for Sisterhood: Narcissism, Projection, and Intersubjective Disruptions in Toni Morrison's Sula and Feminist Communities. Meridians Feminism Race Transnationalism, 13, 28-55.

https://doi.org/10.2979/meridians.13.2.03

[10] Blackburn, S. (1973) You Still Can't Go Home Again. New York Times Book Review, 3-30.

[11] Christian, B. (1985) Black Feminist Criticism: Perspectives on Black Women Writers. Pergamon Press, New York.

[12] Mckee, P. (1996) Spacing and Placing Experience in Toni Morrison's Sula. Modern Fiction Studies, 42, 1-30. https://doi.org/10.1353/mfs.1995.0009

[13] Nedaee, N. and Salami, A. (2017) Toward an Affective Problematics: A DeleuzeGuattarian Reading of Morality and Friendship in ToniMorrison's Sula. Journal of the Spanish Association of Anglo-American Studies, 39, 113-131.

[14] Mayberry, S.N. (2003) Something Other than a Family Quarrel: The Beautiful Boys in Morrison's Sula. African American Review, 37, 517-534.

https://doi.org/10.2307/1512384

[15] Morrison, T. (2004) Sula. Vintage Books, New York.

[16] Fulton, L.W. (2006) A Direction of One's Own: Alienation in Mrs. Dalloway and Sula. African American Review, 40, 67-77. 